\title{
Structural Analysis Using Aeromagnetic Data: Case Study of Parts of Southern Bida Basin, Nigeria and the Surrounding Basement Rocks
}

\author{
John U. Megwara ${ }^{1} \&$ Emmanuel E. Udensi ${ }^{2}$ \\ ${ }^{1}$ Nigerian Geological Survey Agency, Kaduna, Nigeria \\ ${ }^{2}$ Federal University of Technology, P.M.B. 65, Minna, Nigeria \\ Correspondence: John U. Megwara, Nigerian Geological Survey Agency, P.M.B. 2007, Kaduna, Nigeria. E-mail: \\ megwarauj@yahoo.com
}

Received: December 13, $2013 \quad$ Accepted: January 4, $2014 \quad$ Online Published: June 13, 2014
$\begin{aligned} & \text { doi:10.5539/esr.v3n2p27 } \\ & \text { URL: http://dx.doi.org/10.5539/esr.v3n2p27 }\end{aligned}$

\begin{abstract}
Structural analysis using aeromagnetic data over parts of southern Bida (Nupe) basin, Nigeria and the surrounding basement rocks was carried out to highlight linear structures and infer the effects of such features on the tectonic events in the survey area. The basin consists of the basal Lokoja Formation, overlain by the Patti Formation and capped by the Agbaja Formation. The basal Lokoja Formation is a sequence of matrix supported conglomerates and sandstones overlying the Pre-Cambrian to lower Palaeozoic basement. Magnetic rocks (iron ore) occur at the central, north eastern and south southern sections of the study area. Trend characteristics of magnetic lineaments were highlighted using the Euler deconvolution method. Werner and Euler deconvolution of aeromagnetic data profiles were utilized to determine the depth to magnetic sources. Depth to magnetic sources along aeromagnetic data profiles ranges from $0.01 \mathrm{~km}$ to $0.51 \mathrm{~km}$ with an average value of $0.128 \mathrm{~km}$. Deductions made from the research are; mineralization is structurally controlled in parts of the survey area with kaolin occurring along a lineament around Share, western part of the survey area. The occurrence of subsurface linear structures may be due to discontinuities caused by faulting of country rock. Lineaments' trends inferred include the east-west, north-south, northeast-southwest, north northeast-south southwest and northwest-southeast directions, with the north northeast-south southwest trend being dominant. Werner deconvolution plots for profiles $\mathrm{ZZ}$ and $\mathrm{HH}$ located at the central and southern sections of the survey area respectively; are inferred to be basement rock fractures beneath the sedimentary rock.
\end{abstract}

Keywords: basement, basin, lineaments, magnetics, trend

\section{Introduction}

The interpretation of aeromagnetic maps involves interpreting the basement structures and detailed examination of structures and lithologic variations in the sedimentary section. Magnetic basement is an assemblage of rocks that underlie sedimentary basins and may also outcrop in places (Onyedim \& Awoyemi, 2006). In many sedimentary basins, magnetic anomalies arise from secondary mineralization along fault planes, which are often revealed on aeromagnetic maps as surface linear features. Most mineral deposits are related to some type of deformation of the lithosphere, and most theories of ore formation and concentration embody tectonic or deformational concepts (O'Leary et al., 1976; Ananaba \& Ajakaiye, 1987). Some lineament patterns have been defined to be the most favourable structural conditions in control of various mineral deposits (Megwara \& Udensi, 2013). They include the traces of major regional lineaments, the intersection of major lineaments or both major (regional) and local lineaments, lineaments of tensional nature, local highest concentration (or density) of lineament, between echelon lineaments, and lineaments associated with circular features. Linear features are clearly discernible on aeromagnetic maps and often indicate the form and position of individual folds, faults, joints, veins, lithologic contacts, and other geologic features that may lead to the location of individual mineral deposits. They often indicate the general geometry of subsurface structures of an area thereby providing a regional structural pattern (Onyewuchi et al., 2012).

Consequent on the relevance of linear structures aforementioned, Udensi et al. (2003a) showed that there is evidence of the St. Paul's and Romanche Fracture Zones within the Bida basin. Idornighie and Olorunfemi (1992) revealed that the bedrock at the south central part of the Bida basin is highly faulted: two sets of faults trending in a northwest-southeast and northeast-southwest direction. Udensi et al. (2003b) also revealed that the genesis 
of the Bida basin occurred closely connected with the crustal movements of the Santonian Orogeny of the southwestern Nigeria and the nearby Benue Trough. Ojo (1990) indicated that a deep-seated rift may exist in the crust under the Bida basin, Nigeria due to the presence of large bodies of basic rocks identified by the results.

In this study; tilt angle, first order vertical derivative, Werner and Euler deconvolution methods were utilized to study magnetic lineaments with emphasis on their trend and depth to sources. The research covers parts of southern Bida basin, Nigeria and the surrounding basement rocks. The survey area is bounded by a longitude range of $4.5^{\circ} \mathrm{E}$ to $8.0^{\circ} \mathrm{E}$ and latitude range of $8.0^{\circ} \mathrm{N}$ to $9.0^{\circ} \mathrm{N}$. Figure 1 shows the study area in black outline.

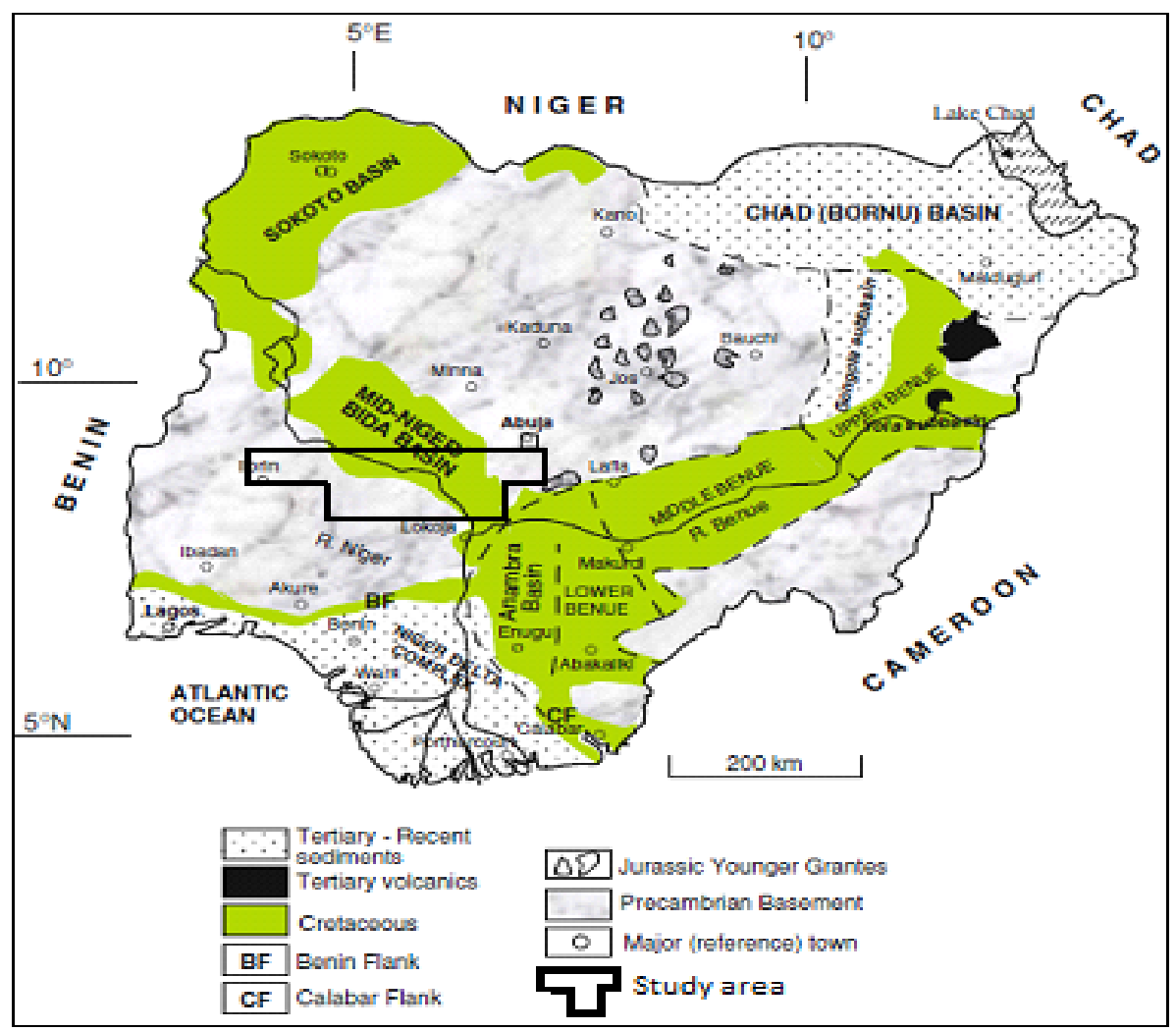

Figure 1. Geological map of Nigeria showing the study area (Source: Obaje, 2009)

\section{Geology}

The southern Bida basin section of the study area (Figure 2) is Cretaceous (136-65 Ma) and forms part of the larger Bida basin. In the basin section, the Pre-Cambrian (4600-570 Ma) to lower Paleozoic (570-500 Ma) basement gneisses and schist is overlain by alternating shales, siltstones, claystones and sandstones (Obaje, 2009; Obaje et al., 2011). The sandstones (Nupe) consist of slightly cemented fine to coarse-grained sandstones and siltstones with interbedded thin beds of carbonaceous shales and clays. The basin consists of the basal Lokoja Formation, overlain by the Patti Formation and capped by the Agbaja Formation. The basal Lokoja Formation is a sequence of matrix supported conglomerates and sandstones overlying the Pre-Cambrian to lower Paleozoic basement. Depositional environments are predominantly within fluvial systems of a continental setting. Patti Formation consists of dark grey carbonaceous shales; mudstones and siltstones representing flood plains to shallow marine deposits with likely organic rich intervals. Agbaja Formation is made up of ferruginised oolitic and kaolinitic mudstone of a marginal environment (Akande et al., 2005).

The surrounding Pre-Cambrian basement rocks consist of a suit of Pre-Cambrian gneisses, migmatites and metasedimentary schist crosscut by intrusive granitoids (Shekwolo, 1992). The Pre-Cambrian basement rocks experienced severe deformation during the late Pan-African phase, and developed megashears that were reactivated during the late Campanian-Maastrichtian (Braide, 1990). The gneisses and metasedimentary schist are found mostly as flat lying outcrops (Shekwolo, 1992). 


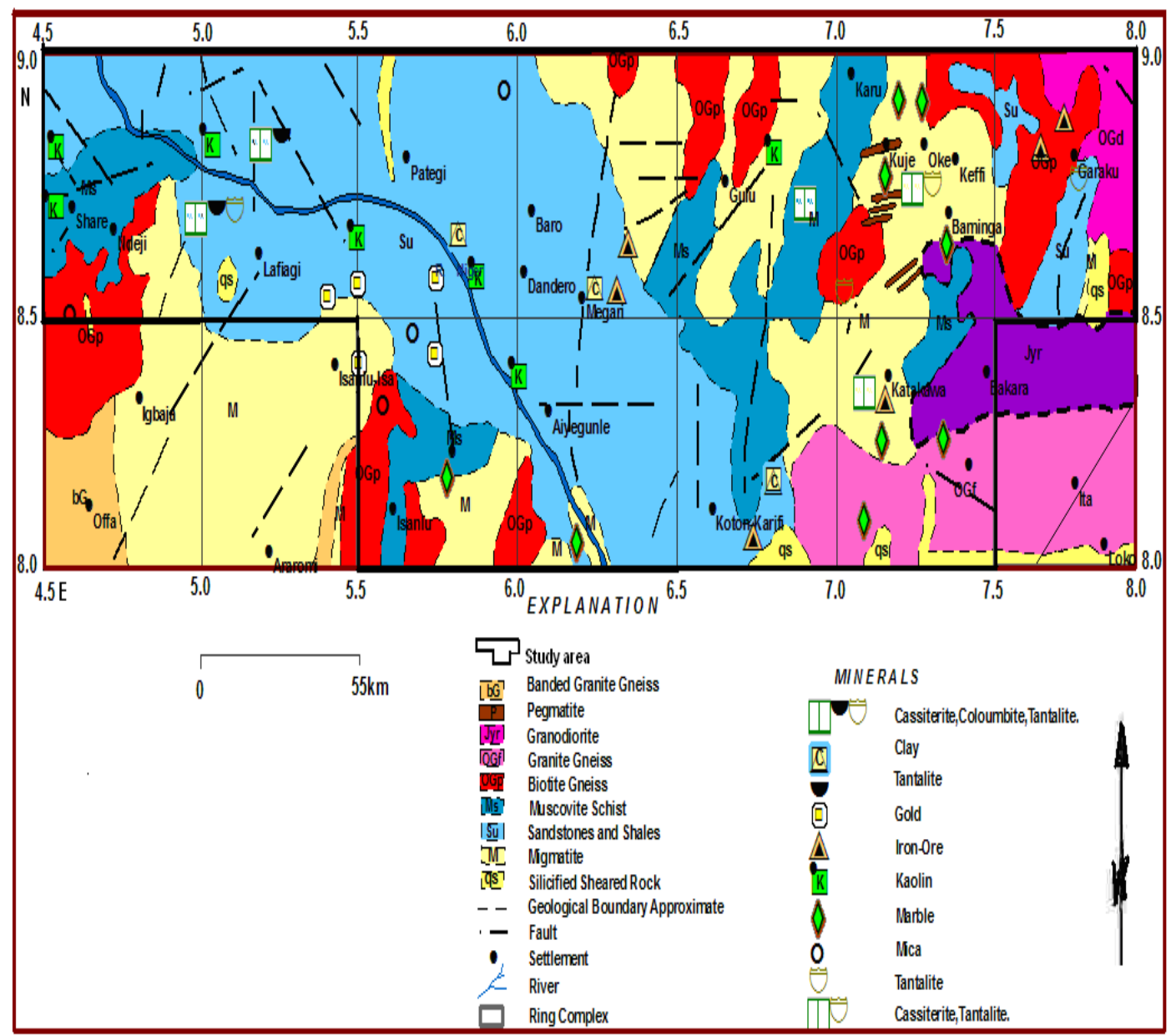

Figure 2. Geological and mineral map of the survey area (Adapted from the geological and mineral map of Nigeria, 2009, Nigerian Geological Survey Agency)

\subsection{Structural Geology}

Lineaments are major topographical features or geological structures that could be of regional extent usually in linear or curvilinear continuous or discontinuous over an entire length. Lineaments may result from faults, joints, folds, contacts or other geological reasons, and are found in igneous, sedimentary and metamorphic rocks. Lineament-mineral association is possible through the process of mineralization. That is the introduction of minerals into pre-existing rocks either in vein placement or in estimated form. Ananaba and Ajakaiye (1987) showed good correlation between areas of high lineament density and the areas where there is occurrence of most primary minerals such as gold, iron ore, cassiterite, tantalite, clay and uranium. Ajakaiye et al. (1991) suggested that magnetic lineaments with definite characteristics exist within the Nigerian continental landmass.

The lineament map (Figure 3), shows several lineaments trending in various directions namely north-south, east-west, northeast-southwest and northwest-southeast. Both basement and sedimentary sections have linear features trending in north-south and east-west directions. The red boxes on the map indicate sections of the map where there are cross cutting of lineaments. The cross cutting of lineaments occurs mostly within the southern Bida basin section. As shown in Figure 3 the sections characterized with the cross cutting of lineaments are not zones of mineralization (if they are associated with mineralization, the minerals may be insitu). However, Figure 2 illustrates lineament-mineral association within the research area, as lineaments are observed associated with the occurrence of gold and kaolin around Isanlu and Share areas, respectively.

\section{Materials and Methods}

\subsection{Materials}

Data acquisition and analysis: Airborne magnetic survey of a substantial part of Nigeria was carried out by the Nigerian Geological Survey Agency between 1974 and 1980. The magnetic information consists of profiles or 
flight lines plotted on continuous strip chart. The aeromagnetic data was collected at a nominal flight altitude of $152.4 \mathrm{~m}$ along north-south flight lines spaced approximately $2 \mathrm{~km}$ apart. The airborne survey data were published in the form of $1 / 2$ degrees by $1 / 2$ degrees contour maps of total magnetic intensity (TMI) on a scale of 1:100,000. The research area is made up of 11 aeromagnetic maps acquired from the Agency. These are numbers: 202, 203, 204, 205, 206, 207, 208, 225, 226, 227 and 228.

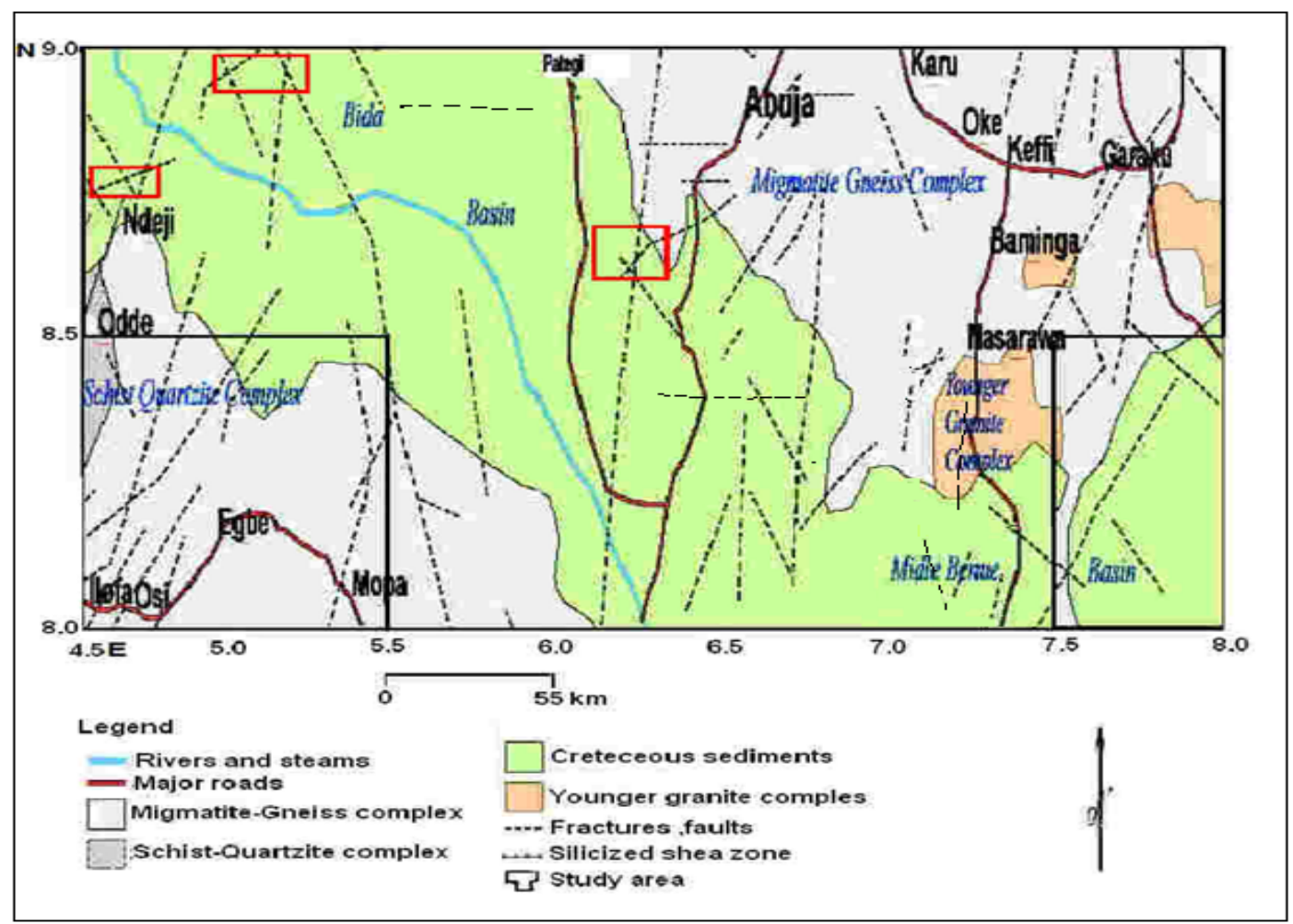

Figure 3. Lineament map of the study area (Adapted from the Lineament Map of Nigeria, 1994, Nigerian Geological Survey Agency)

The data for this survey was obtained from the digitization of uninterpreted TMI contour maps. The digitization method adopted for this study is the manual visual interpolation method. This method involves drawing 19 straight lines vertically and horizontally at equal spacing on a tracing paper to form a grid layout. The boundaries of the layout must coincide with the boundaries of the aeromagnetic map layout to be used for digitization (Udensi, 2000). The layout is overlain on the aeromagnetic map and magnetic values are read from the cross points on the grid system. At grid points where contours do not cross, visual interpolation to the closest contour line is made to estimate the magnetic value at the grid point. Since the grid points are evenly spaced, it enables the determination of the longitude and latitude coordinate values of each grid point.

The data from each digitized map is stored in a 19 by 19 coding sheet. Each sheet contains records of the boundary longitude and latitude, the map number and name of the town over flown. The problem of boundary (edge) effect has to be solved before the combined dataset is produced. This problem is illustrated in Table 1.

Table 1. A block consisting of 11 small maps

\begin{tabular}{ccccccc}
\hline 202 & 203 & 204 & 205 & 206 & 207 & 208 \\
Share & Lafiagi & Pategi & Baro & Gulu & Kuje & Keffi \\
\hline & 225 & 226 & 227 & 228 & \\
& & Isanlu & Aiyegunle & Koton karfi & Katakwa & \\
\hline
\end{tabular}

Each number in Table 1 represents an aeromagnetic map measuring $1 / 2$ degree by $1 / 2$ degree on the decimal scale. Each small map contains 19 x 19 digitized magnetic values. At the boundary of two maps, for example maps 202 
and 203, the field values in the last column of map 202 have the same coordinates (latitude and longitude) as the field values at the first column of map 203. Also, at the boundary between map 207 and map 228 for example the field values at the last row of map 207 have the same coordinates as the field values in the first row of map 228 . To have a data set therefore, all magnetic values with the same coordinates must be added and averaged so that there would not be rows and columns of magnetic points with the same coordinates. After solving the problem of boundary edge effect, a $\mathrm{C}^{++}$program Mapro was used to generate the longitude and latitude coordinates of the TMI data. The interval between each data point is 0.0271 units $(\approx 3 \mathrm{~km})$ yielding 2937 data points for the 11 sheets. The $3 \mathrm{~km}$ grid interval imposed a Nyquist frequency of $0.167 \mathrm{~km}^{-1}$.

\subsection{Methods}

Regional-residual separation: The study area does not have complex geology and it has spatial extent, thus, it seemed plausible to assume that the regional field is a first-order polynomial surface. The regional magnetic field data was separated from the residual magnetic field data using the Robust Polynomial Fitting method. Residual magnetic field data was obtained as the deviations of the fitted plane surface from the total magnetic intensity.

Werner deconvolution: The equations for the total magnetic field due to thin sheets and the edges of a thick body (Werner equations) is used to compute the depth to the top, susceptibility contrast, and the dip of these features from a given total magnetic field profile. The term "Werner deconvolution" refers to a set of algorithms whose feature is the linearization of a two-dimensional (2-D) inverse problem for the parameters of a magnetic dike or contact by clearing the denominators of the rational functions that describe their anomalies (Hansen \& Simonds, 1993; Kilty, 1983).

Basic theoretical equations of the Werner deconvolution technique.

For the purpose of direct interpretation, the source bodies can be divided into two types:

1) The bodies whose width is comparable to their depth from the observation plane. These can be called thin bodies, because the edges of these bodies cannot be located easily, with reasonable accuracy.

2) The bodies of considerable lateral extent, whose bounding edges can be separately identified. The expression for the total magnetic field due to thin dikes of any arbitrary dip was given by Werner (1953). Werner's interpretation equations were reproduced by Hartman et al. (1971):

The equation for the magnetic field due to a thin dike is of the form:

$$
\mathrm{F}_{\mathrm{r}}+\mathrm{a}_{0}+\mathrm{a}_{1} \mathrm{x}+\mathrm{b}_{0} \mathrm{~F}+\mathrm{b}_{1} \mathrm{Fx}=\mathrm{x}^{2} \mathrm{~F}
$$

$(\mathrm{x}, 0)$ are the coordinates where the field $\mathrm{F}$ is observed,

$\mathrm{F}_{\mathrm{r}}$ is the unknown ambient noise polynomial of the type:

$$
\mathrm{F}_{\mathrm{r}}=\Delta \mathrm{F}+\mathrm{K}_{\mathrm{F}} \mathrm{x}+\mathrm{K}_{\mathrm{F}}^{1} \mathrm{x}^{2}+\ldots \ldots
$$

and $\mathrm{a}_{0}, \mathrm{a}_{1}, \mathrm{~b}_{0}$, and $\mathrm{b}_{1}$, are related to the properties of the source of the anomaly.

For total magnetic field, $\mathrm{a}_{0}, \mathrm{a}_{1}, \mathrm{~b}_{0}$, and $\mathrm{b}_{1}$, are related to the various parameters as follow:

$$
\begin{gathered}
x_{0}=b_{1} / 2 \\
t_{0}=\left(-b_{0}-b_{1}{ }^{2} / 4\right)^{1 / 2} \\
t M_{11}=\frac{\left(2 a_{0}+a_{l} b_{l}\right) v_{z}-2 a_{l} t_{0} v_{x}}{4 t_{0}\left(v_{x}{ }^{2}+v_{z}^{2}\right)} \\
t M_{11}=-\frac{\left(2 a_{0}+a_{l} b_{l}\right) v_{x}-2 a_{1} t_{0} v_{z}}{4 t_{0}\left(v_{x}{ }^{2}+v_{z}{ }^{2}\right)}
\end{gathered}
$$

where $\mathrm{v}_{\mathrm{x}}$ and $\mathrm{v}_{\mathrm{z}}$ are the direction cosines of the total magnetic field, $\mathrm{x}_{0}$ is the location of the dike, $\mathrm{t}_{0}$ is the depth to the top, $t$ is the thickness, and $\mathrm{M}_{11}$ and $\mathrm{M}_{1}$ are the cross magnetization of the sheet. From $\mathrm{M}_{11}$ and $\mathrm{M}_{1}$, one can determine the susceptibility contrast and the dip of the dike. The same equation \{except for factor $t$ in equations (5) and (6) $\}$ is applicable to the horizontal gradient of the total field for a dipping edge. Therefore, the horizontal gradient can be computed from the total field and the same equations can be used to estimate the source parameters for an edge. Thus, the same algorithm provides solutions for a dike or an edge, and the interpreter can choose the right depth whether the source is a thin dike or a thick body with distinct edges. 
Euler deconvolution: The Euler deconvolution method is based on Euler's homogeneity equation; an equation that relates the magnetic field and its gradient components to the location of the source, with the degree of homogeneity $\mathrm{n}$, which may be interpreted as a structural index (Thompson, 1982). The structural index is a measure of the rate of change with distance of a field. For example, in a magnetic field a narrow two dimensional dike has a structural index of $\mathrm{n}=1$, while a vertical pipe gives $\mathrm{n}=2$.

A solution is recorded if the depth uncertainty of the estimated depth is less than a specified tolerance and the solution is within a limiting distance of the centre of the data window. When the process is stopped, a database file containing the depth solution is obtained as output.

The basic theory of Euler deconvolution technique is given by:

Any three dimensional function $f(x, y, z)$ is said to be homogeneous of degree $n$ if the function obeys the expression:

$$
f(t x, t y, t z)=t^{n} f(x, y, z)
$$

From this, it can be shown that the following (known as Euler's equation) is also satisfied:

$$
x \frac{\partial f}{\partial x}+y \frac{\partial f}{\partial y}+z \frac{\partial f}{\partial z}=n f
$$

The degree of homogeneity, $\mathrm{n}$, can be interpreted as a structural index (SI). A magnetic point dipole corresponds to $\mathrm{n}=3$, while a magnetic pole and a line of magnetic dipoles correspond to $\mathrm{n}=2$; whereas a magnetic dike and an anomalous pipe mass correspond to $\mathrm{n}=1$. Reid et al. (1990) have shown that a magnetic contact will yield an index of 0.5 provided that an offset $\mathrm{A}$ is introduced to incorporate anomaly amplitude, strike and dip factors:

Where

$$
A=\left(x-x_{0}\right) \frac{\partial T_{f}}{\partial x}+\left(y-y_{0}\right) \frac{\partial T_{f}}{\partial y}+\left(z-z_{0}\right) \frac{\partial T_{f}}{\partial z}
$$

Given a set of observed total field data, we can determine an optimum source location $\left(\mathrm{x}_{0}, \mathrm{y}_{0}, \mathrm{z}_{0}\right)$ by solving Euler's equation for a given index $\mathrm{n}$ by least square inversion of the data.

Tilt angle: The tilt angle (Miller \& Singh, 1994; Verduzco et al., 2004; Salem et al., 2007, 2008) is defined as

$$
\theta=\tan ^{-1}\left[\frac{\partial M}{\partial z} / \frac{\partial M}{\partial h}\right]
$$

Where

$$
\frac{\partial M}{\partial h}=\sqrt{\left(\frac{\partial M}{\partial x}\right)^{2}+\left(\frac{\partial M}{\partial y}\right)^{2}}
$$

$\partial \mathrm{M} / \partial \mathrm{x}, \partial \mathrm{M} / \partial \mathrm{y}$ and $\partial \mathrm{M} / \partial \mathrm{z}$ are derivatives of the magnetic field $\mathrm{M}$ in the $\mathrm{x}, \mathrm{y}$ and $\mathrm{z}$ directions.

$$
\begin{aligned}
\frac{\partial M}{\partial z} & =2 K F c \sin d \frac{h \cos (2 I-d-90)-z \sin (2 I-d-90)}{h^{2}+z_{c}{ }^{2}} \\
\frac{\partial M}{\partial h} & =2 K F c \sin d \frac{z_{c} \cos (2 I-d-90)-h \sin (2 I-d-90)}{h^{2}+z_{c}{ }^{2}}
\end{aligned}
$$

where $\mathrm{K}$ is the susceptibility contrast at the contact, $\mathrm{F}$ the magnitude of the magnetic field, $\mathrm{c}=1-\cos ^{2} i \sin ^{2} \mathrm{~A}, \mathrm{~A}$ the angle between the positive $\mathrm{h}$-axis and the magnetic north, $i$ the ambient field inclination, $\tan I=\tan i / \cos \mathrm{A}$, $\mathrm{d}$ the dip (measured from the positive $\mathrm{h}$-axis) and all trigonometric quantities are in degrees (Salem et al., 2007).

For vertical contacts,

$$
\frac{\partial M}{\partial z}=2 K F c \frac{h}{h^{2}+z_{c}^{2}}
$$




$$
\frac{\partial M}{\partial h}=2 K F c \frac{z_{c}}{h^{2}+z_{c}^{2}}
$$

Substituting Equations 14 and 15 in 10, this gives

$$
\theta=\tan ^{-1}\left[\frac{h}{z_{c}}\right]
$$

Equation 16 indicates that the value of the tilt angle above the edges of the contact is $0^{\circ}(\mathrm{h}=0)$ and equal $45^{\circ}$ when $\mathrm{h}=z_{c}$ and $-45^{\circ}$ when $\mathrm{h}=-z_{c}$. This suggests that contours of the magnetic tilt angle can identify both the location $\left(\theta=0^{\circ}\right)$ and depth (half the physical distance between $\pm 45^{\circ}$ contours) of contact-like structures (Salem et al., 2007).

Linear structures mapping using Landsat data: Landsat Thematic Mapper (Landsat-TM) imagery covering the survey area was obtained from the Global Land Cover Facility and used to map linear features in the study area. The raw data was geo-referenced using the coordinates of the topographic sheets covering the research area. Image enhancement operations carried out include contrast stretching, spatial filtering and edge detection, which were done to enhance sharpness of the satellite image for better visual interpretation, reduce noise in the image and aid structural interpretation.

\section{Results and Discussion}

\subsection{Results}

The general trending fabric of TMI anomalies (Figure 4) is the northeast-southwest direction. The TMI values range from a minimum value of 7630 nano tesla to a maximum value of 7930 nano tesla. Since sedimentary rocks are characterized by low susceptibility values, a northeast-southwest trending magnetic high anomaly occurring at the central part of the basin section results from underlying magnetic basement rocks. The residual magnetic field (Figure 5) indicates a general trending fabric of anomalies in the northeast-southwest direction, having magnetic values ranging from a minimum of -458.15 nano tesla to a maximum of 129.12 nano tesla. The survey area is not vast in expanse; both first and second order regional magnetic field contours are linear; a first order regional magnetic field was adopted for this study. The regional magnetic field (Figure 6) shows contour lines trending in a dominant northwest-southeast direction; and this is in agreement with trend of the basin. There is no significant difference between the features of both first and second order residual magnetic field anomalies; a first order residual magnetic field was adopted for this study. Rivers' courses in the survey area are structurally controlled; trending mainly in the northwest-southeast and northeast-southwest directions (Figures 7 and 8). The Rose diagram (Figure 9) generated from Landsat data; also highlights a dominant north northeast south southwest direction of linear structures.

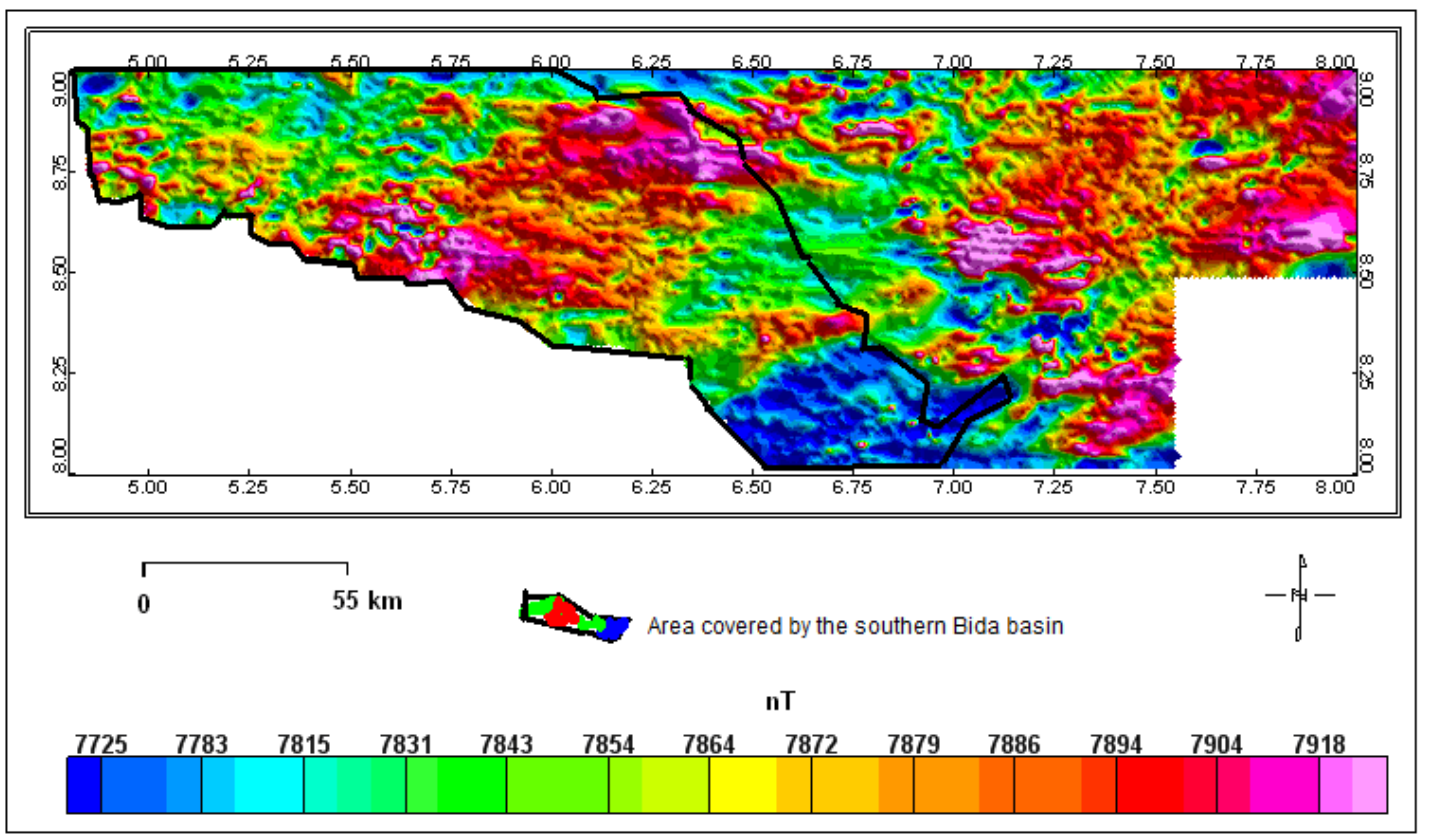

Figure 4. Total magnetic intensity map of the study area 


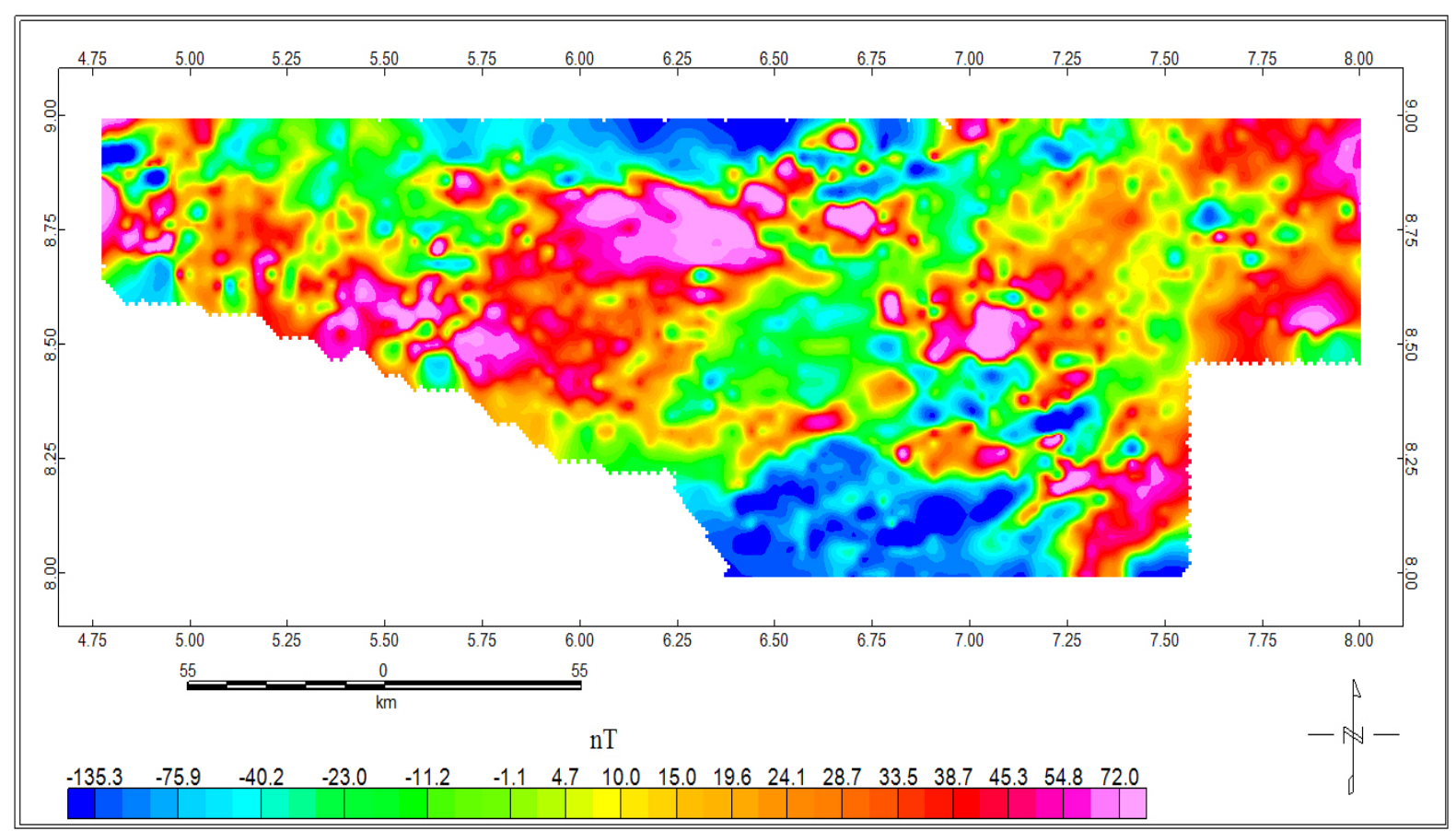

Figure 5. Residual magnetic field

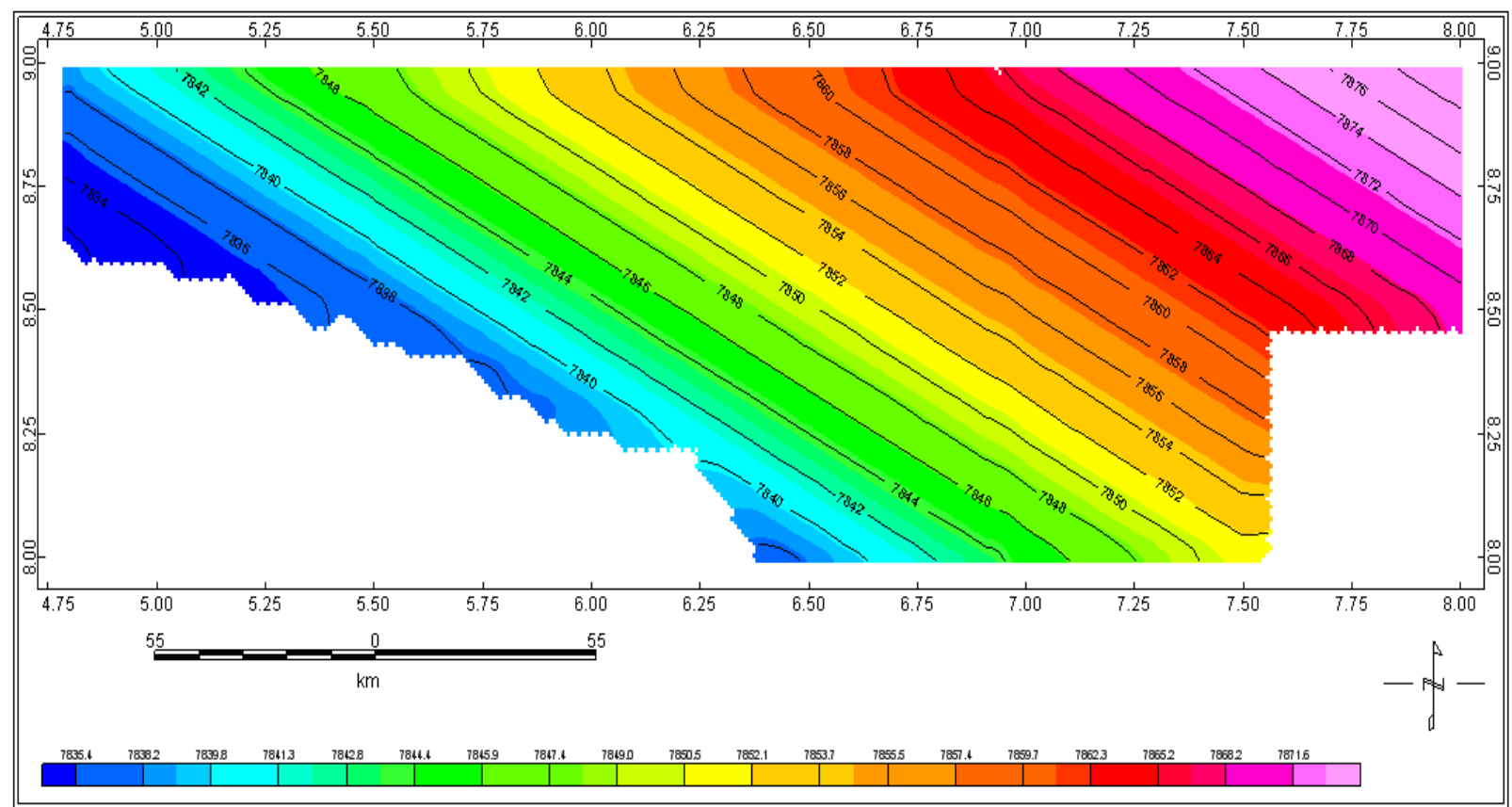

Figure 6. Regional magnetic field 


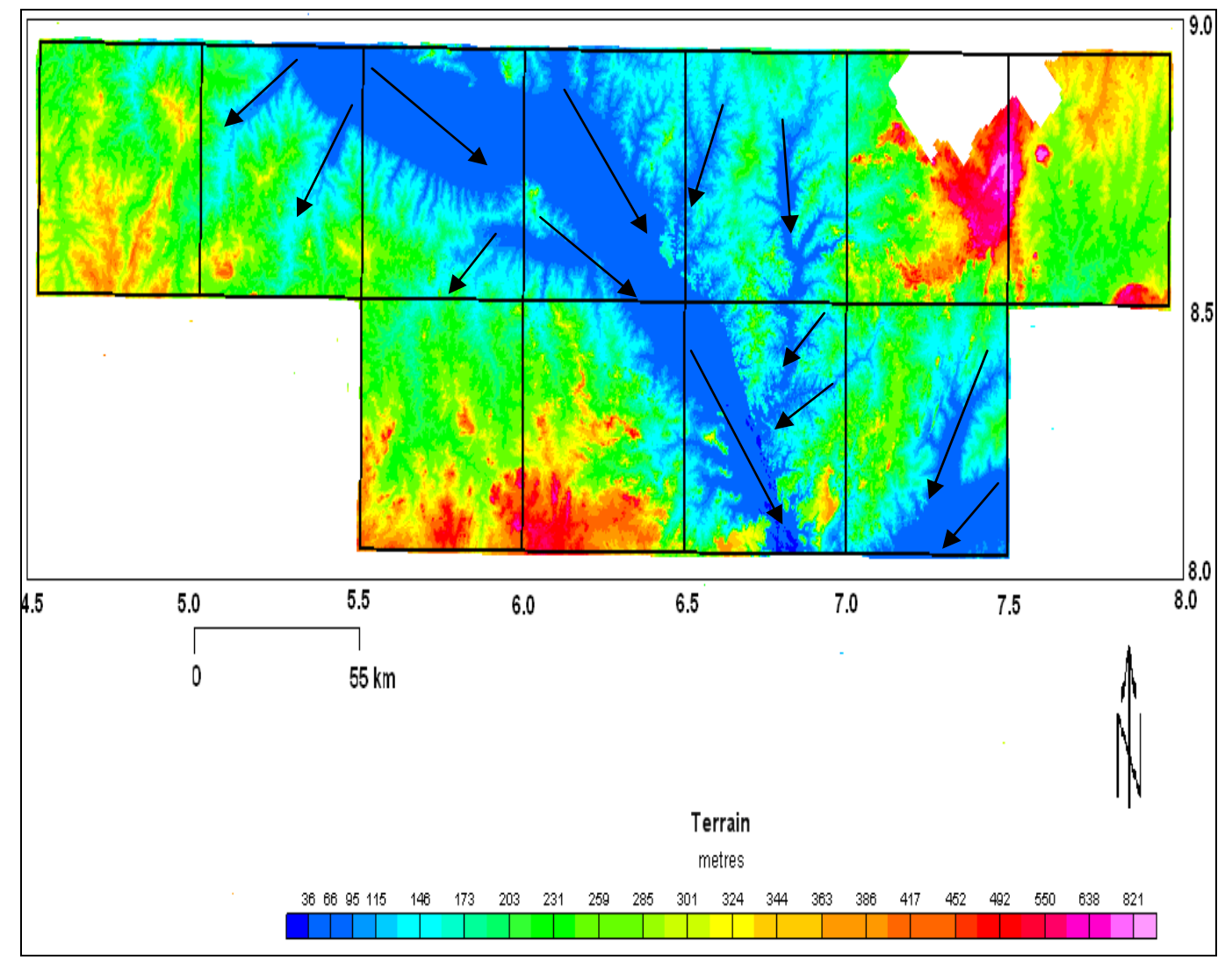

Figure 7. Terrain map of the study area showing that the drainage pattern is structurally controlled as shown by the black arrows

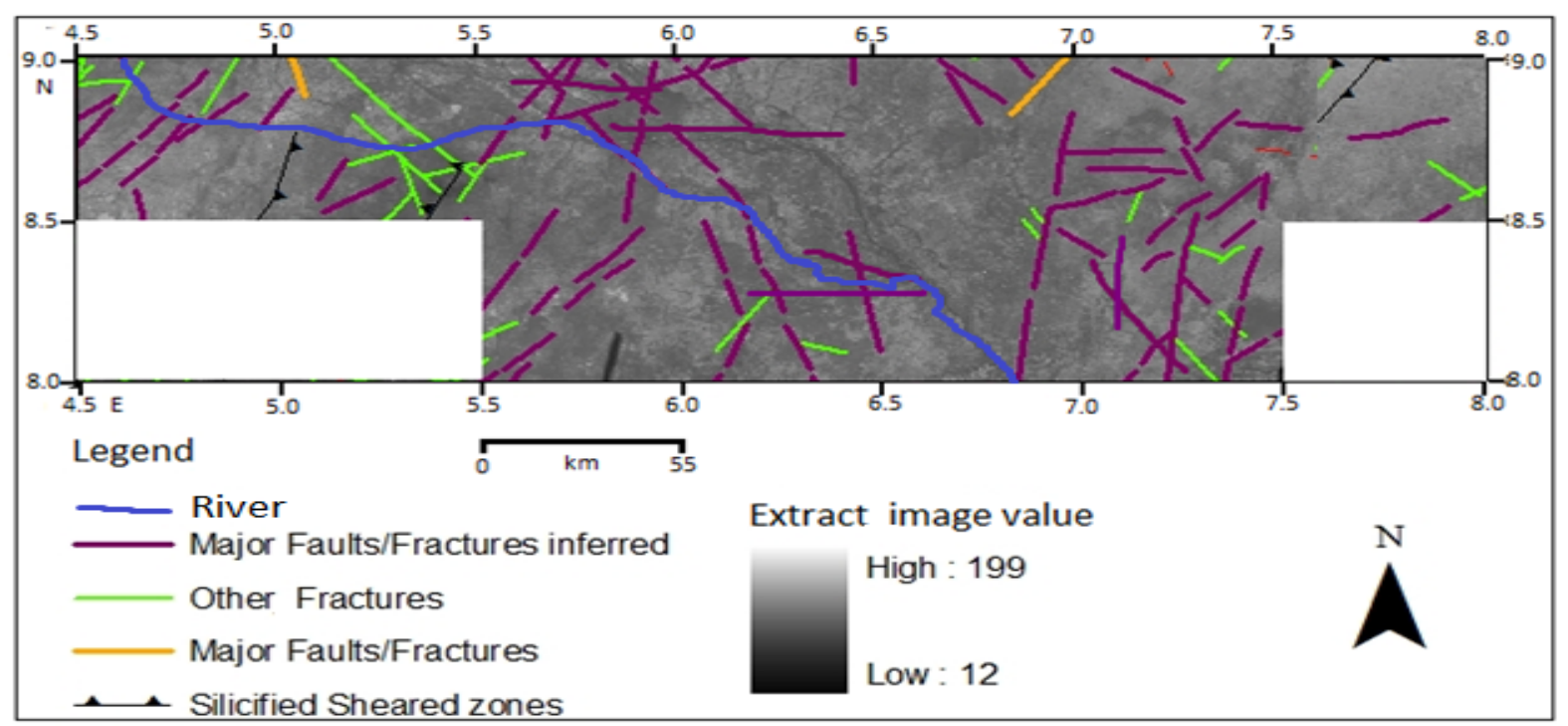

Figure 8. Lineaments generated from Landsat thematic mapper image of the study area: highlights east-west, northwest-southeast and northeast-southwest directions of linear structures 


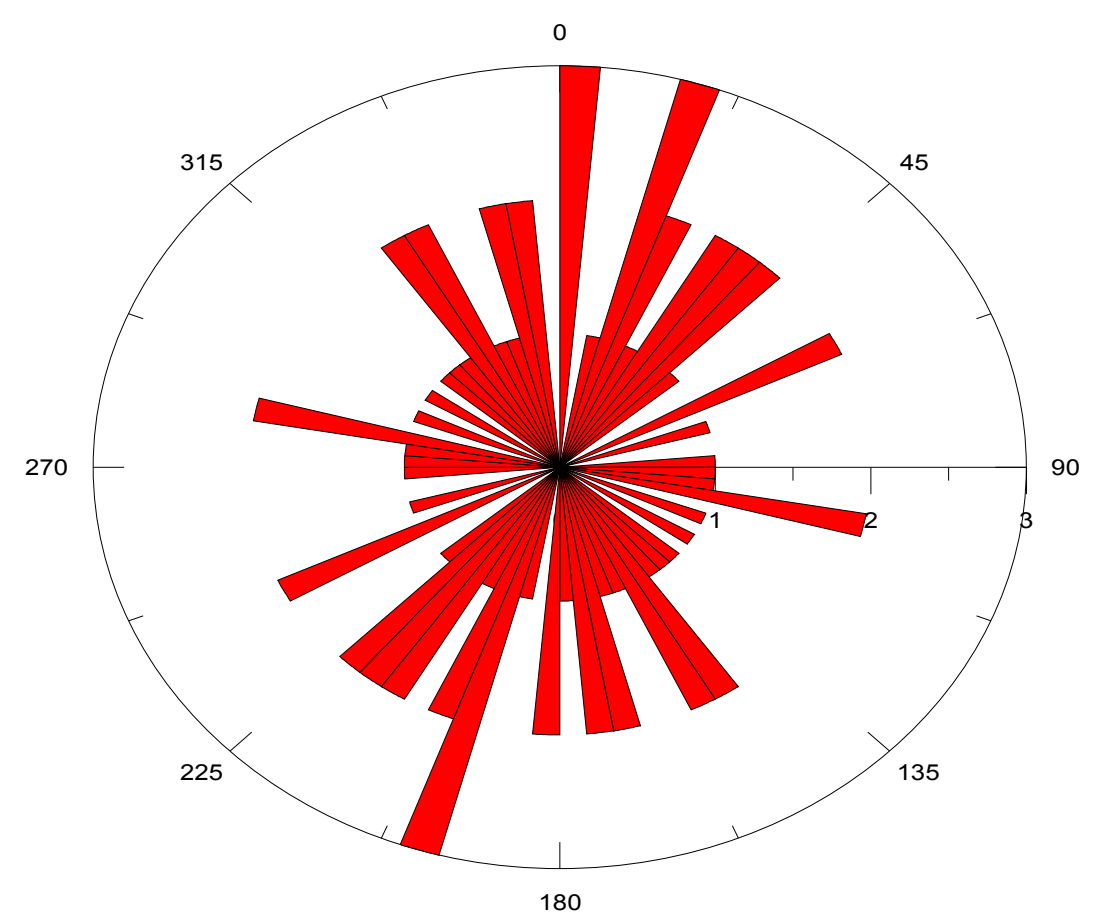

Figure 9. Rose diagram of lineaments in the study area generated from Landsat data

Werner deconvolution of aeromagnetic data profiles: The magnetic profiles are shown in Figure 10. Profile GG is an east-west line drawn across a north-south trending anomaly $(\mathrm{g})$ located at the north- northwestern part of the map. Profile $\mathrm{ZZ}$ is an east-west line drawn across a north-south trending anomaly (z) located at the central part of the map. Profile PP is an east-west line drawn across a north-south trending anomaly (p) located at the northern part of the map. Profile FF is a north-south line drawn across an east-west trending anomaly (f) located at the east central part of the map. Profile HH is a north-northwestern line drawn across a north-northeastern trending anomaly (h) located at the southern part of the map.

A Fortran programme Werner applied to the five TMI data profiles: GG, HH, ZZ, PP and FF (Figure 10), yielded the Werner deconvolution solutions Figures (11-15). Origin Pro version 8.0 software was used to obtain the Werner plots. The results show that depth to magnetic sources ranges from $0.01 \mathrm{~km}$ to $0.50 \mathrm{~km}$. The contact and dike Werner deconvolution models adopted by Jain (1976) were employed for analyzing the Werner solutions.

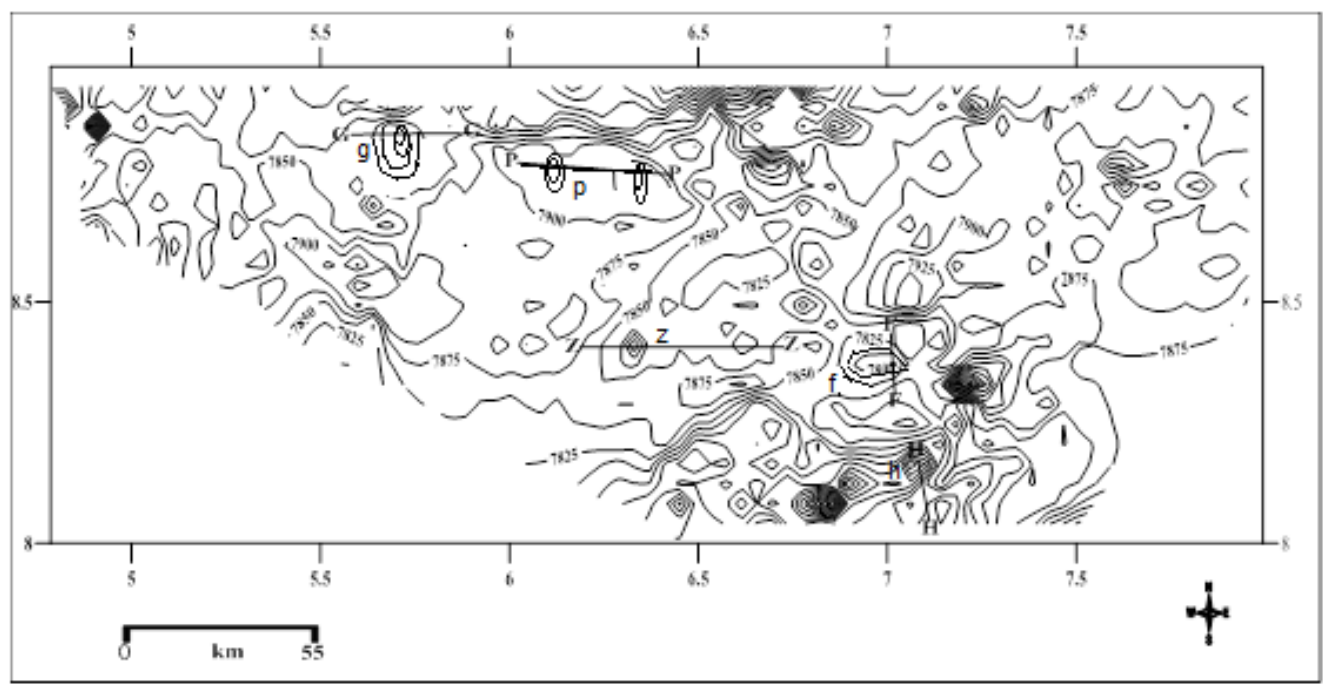

Figure 10. Contoured total magnetic intensity map showing aeromagnetic data profiles 


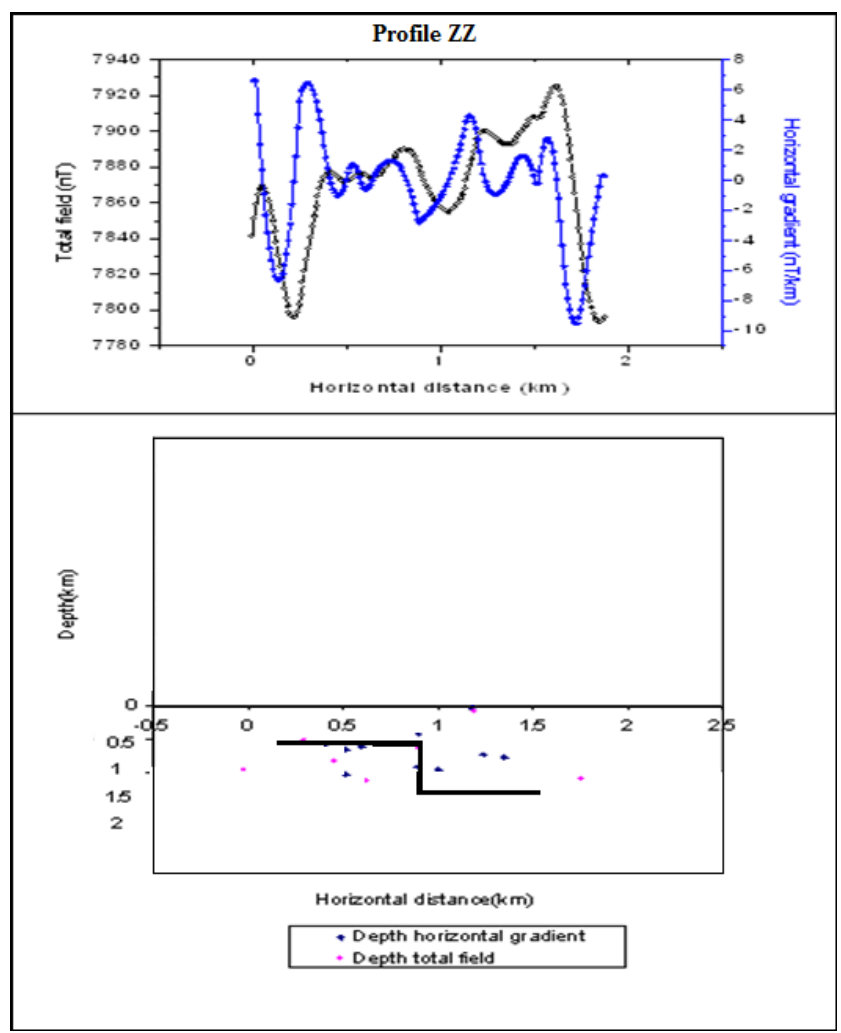

Figure 11. Werner plot for profile ZZ

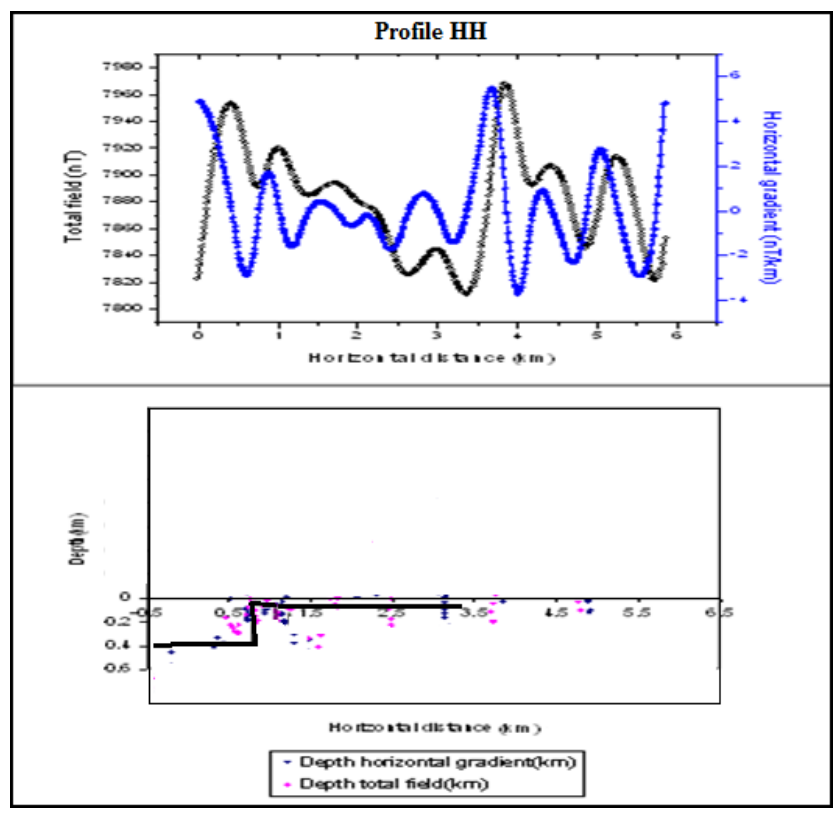

Figure 12. Werner plot for profile $\mathrm{HH}$ 


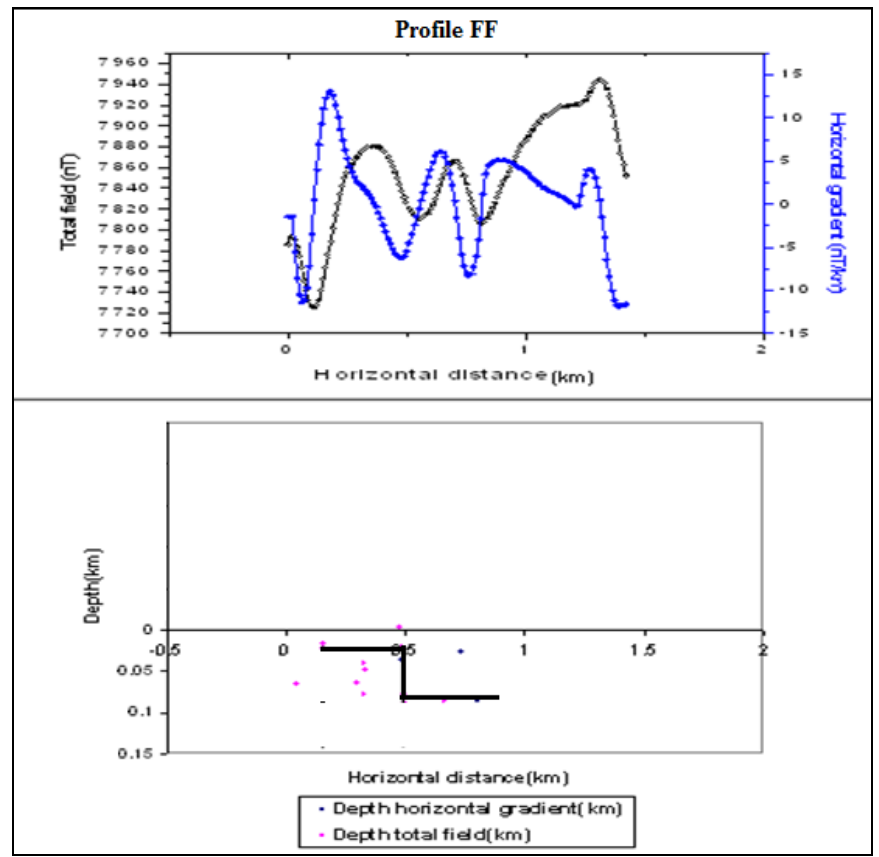

Figure 13. Werner plot for profile FF

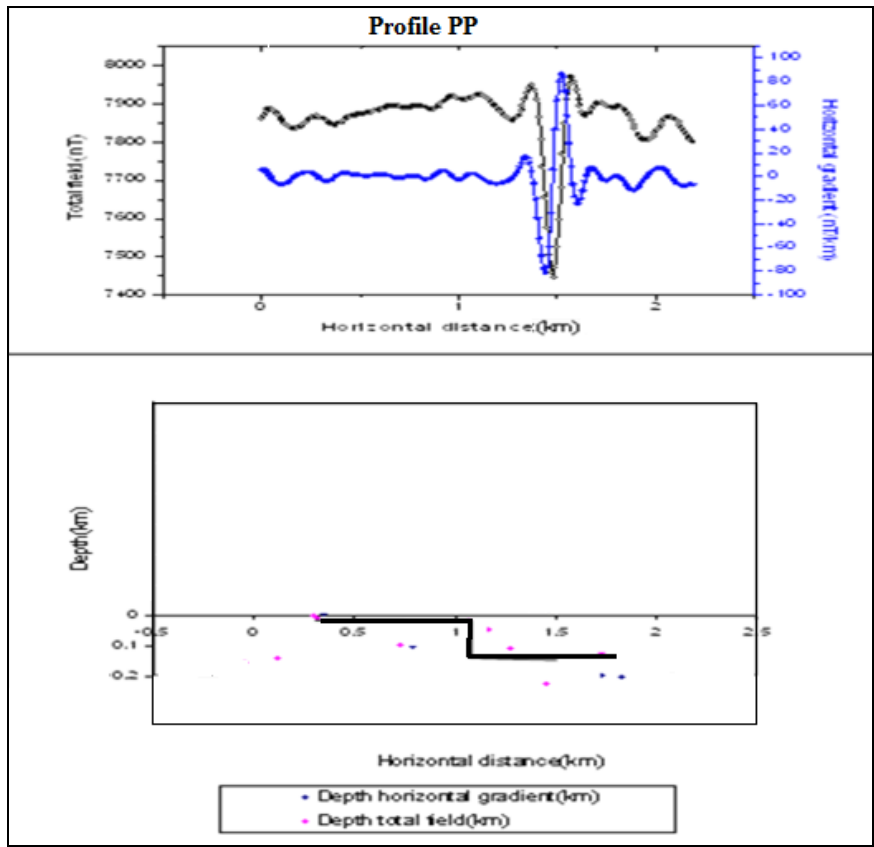

Figure 14. Werner plot for profile PP 


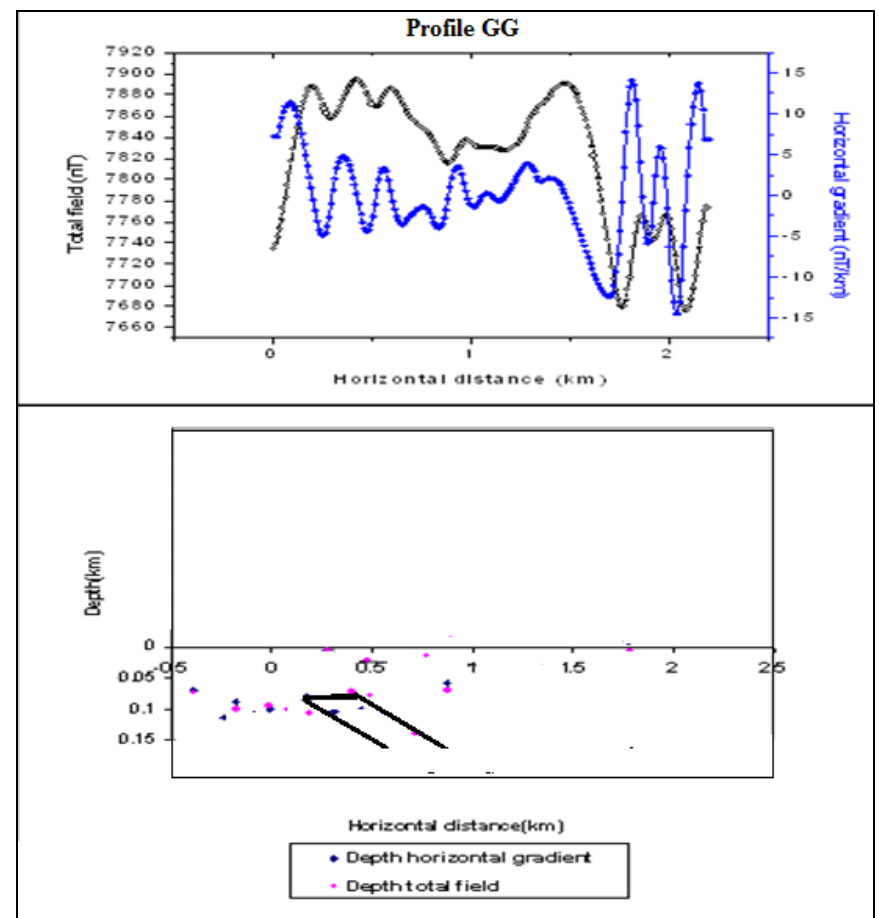

Figure 15. Werner plot for profile GG

\subsection{Discussion}

Werner solutions for profiles $\mathrm{ZZ}$ and $\mathrm{HH}$ are shown in Figures 11 and 12. Using the Werner contact model, the features are inferred to be basement rock fractures beneath the sedimentary rock, occurring at about $0.50 \mathrm{~km}$ and $0.01 \mathrm{~km}$ respectively; from the surface and may be filled with mineral vein. Werner solutions for profiles FF and $\mathrm{PP}$ are shown in Figures 13 and 14; deduced to be crevices in the basement rock occurring at about $0.032 \mathrm{~km}$ and $0.020 \mathrm{~km}$ respectively from the surface. Using the Werner dike model; the Werner solution for profile GG shown in Figure 15 is inferred to be a dipping dike occurring at about $0.08 \mathrm{~km}$ from the surface.

Werner and Euler deconvolution of magnetic data profiles both yielded depth to sources ranging from $0.01 \mathrm{~km}$ to $0.50 \mathrm{~km}$ and $0.015 \mathrm{~km}$ to $0.51 \mathrm{~km}$ respectively. Thus, this indicates an agreement on the results from both methods. The Euler deconvolution, shaded relief first vertical derivative of TMI and tilt angle maps (Figures 16 a, $\mathrm{b}$ and c) all highlighted correlational magnetic profiles on similar location which mark out traces of linear features. The linear features may be due to discontinuities resulting from faulting of host rock. 


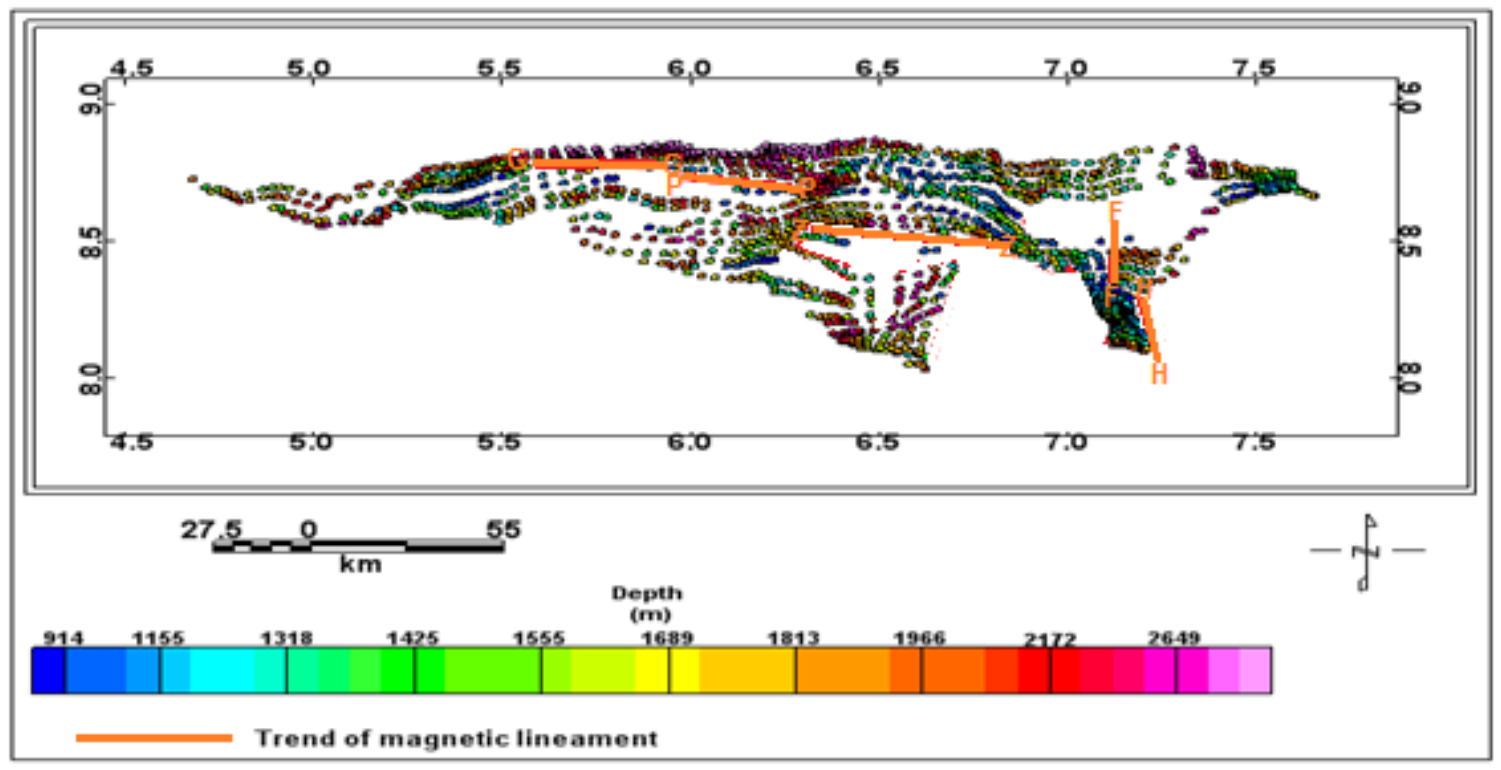

(a) Euler deconvolution

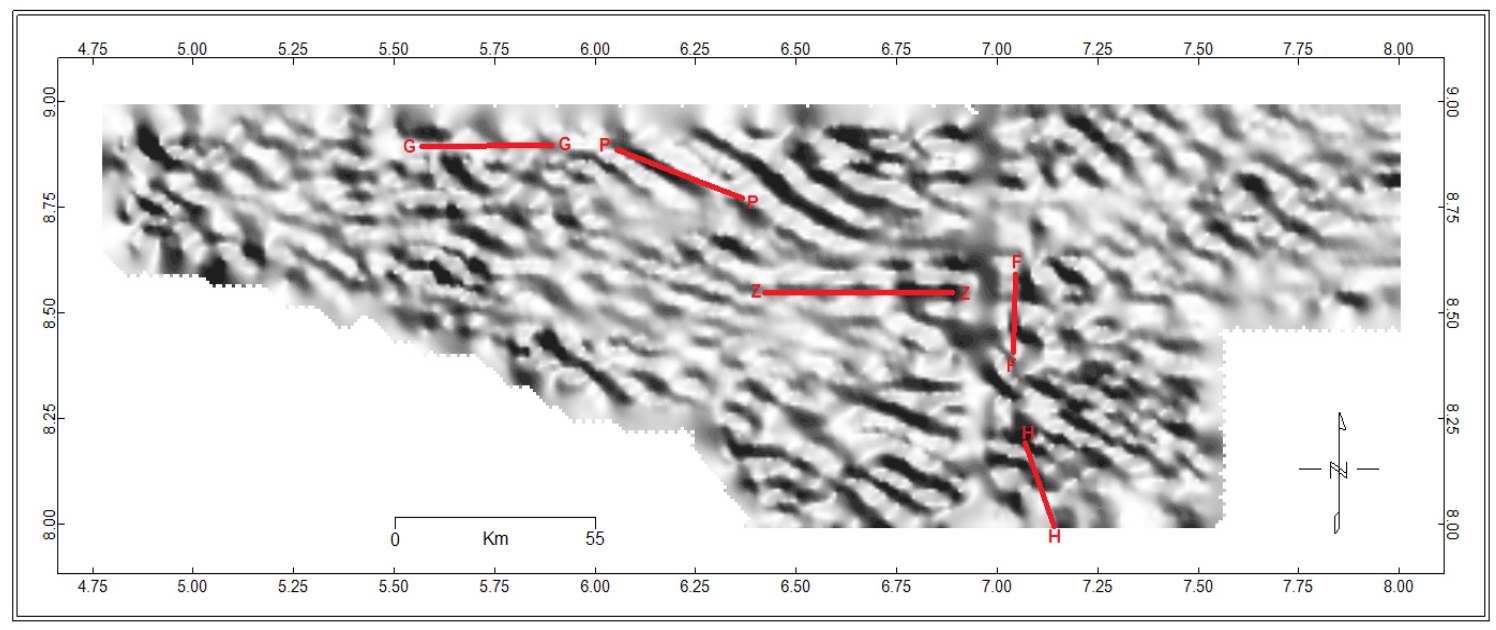

(b) Shaded relief first vertical derivative of TMI

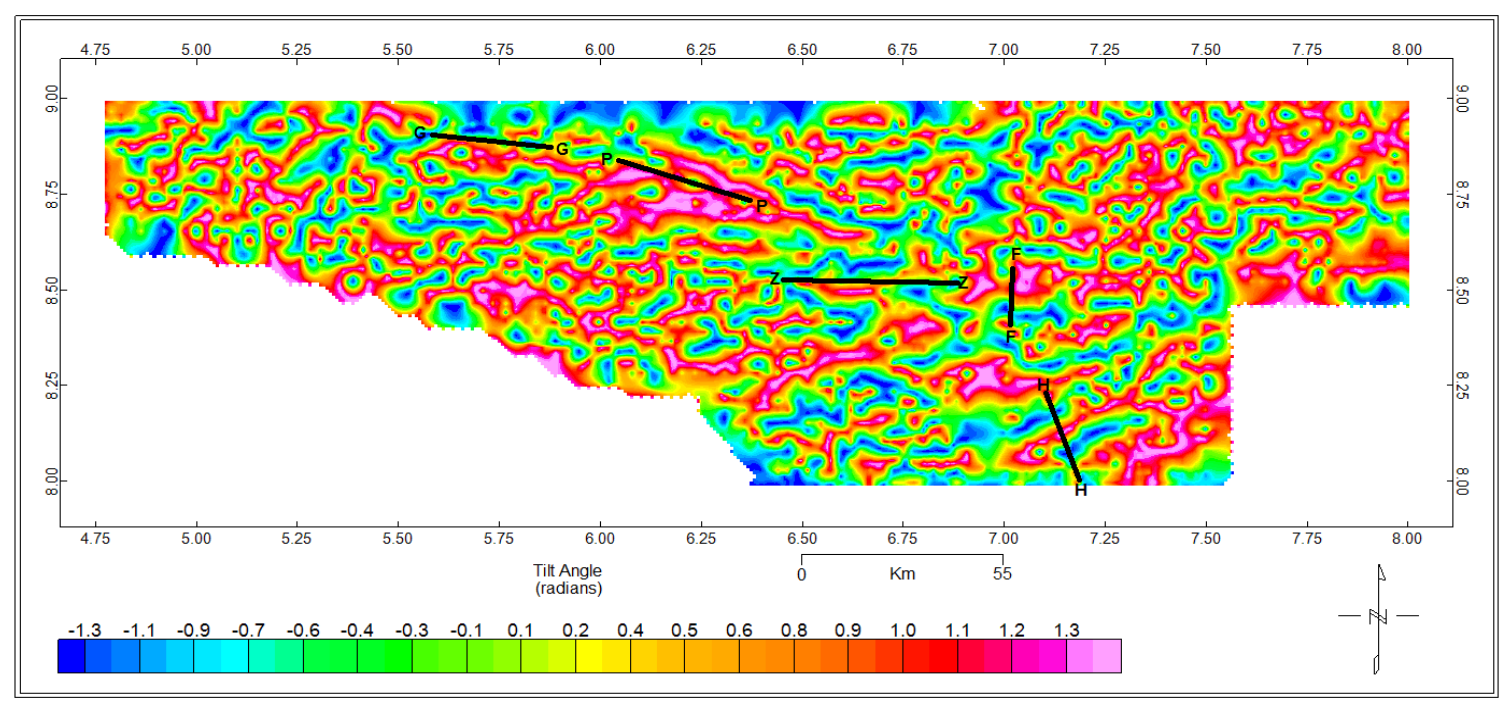

(c) Tilt angle

Figure 16. Correlation of Euler deconvolution, shaded relief first vertical derivative and tilt angle maps 


\section{Conclusion}

The drainage pattern of the study area is dendritic and structurally controlled. Lineaments inferred from the study trend prominently in the north northeast - south southwest (NNE-SSW) direction. These linear structures are suggested as pegmatites, quartz veins or faults cross-cutting the country rock.

The TMI high within the basin section may result from basement rock uplift beneath the sedimentary rocks. Basement rock uplift may be caused by highly magnetic basic igneous intrusions. Both first and second order Robust Polynomial Fitting applied to TMI data are expressive for regional and local features; with geology of the survey area being non-complex.

The depth to sources along magnetic profiles is low indicating surficial magnetic sources which may be attributed to thin sedimentary cover overlying the basement rock. Werner deconvolution of magnetic Profile GG at the north-northwestern section of the research area infers the occurrence of a near surface northwest-southeast dipping basic igneous intrusion which may be attributed to the existence of a rift in the crust beneath the basin.

\section{Acknowledgements}

The authors are grateful to the Nigerian Geological Survey Agency, Abuja for their sponsorship of the training on the application of Oasis montaj 7.0.1, Encom PA 9.0, Model Vision 8.0, QuickMag 3.0 and ArcGIS 10.0 softwares. The contribution of Mr. Stephen O. Akinpelumi, eHealth Systems Africa Ltd., Nigeria is highly appreciated.

\section{References}

Ajakaiye, D. E., Hall, D. H., Ashiekaa, J. A., \& Udensi, E. E. (1991). Magnetic anomalies in the Nigerian continental mass based on aeromagnetic surveys. Tectonophysics, 192(1), 211-230. http://dx.doi.org/10.1016/0040-1951(91)90258-T

Akande, S. O., Ojo, O. J., Erdtmann, B. D., \& Hetenyi, M. (2005). Paleoenvironments, organic petrology and Rock-Eval studies on source rock facies of the Lower Maastrichtian Patti Formation, southern Bida Basin, $\begin{array}{lllll}\text { Nigeria. Journal of African } & \text { Earth }\end{array}$ http://dx.doi.org/10.1016/j.jafrearsci.2005.07.006

Ananaba, S. E., \& Ajakaiye, D. E. (1987). Evidence of tectonic control of mineralization in Nigeria from lineament density analysis A Landsat-study. International Journal of Remote Sensing, 8(10), 1445-1453. http://dx.doi.org/10.1080/01431168708954788

Braide, S. P. (1990). Sedimentation and tectonics in the southern Bida Basin, Nigeria: depositional response to varying tectonic context. AAPG Bulletin (American Association of Petroleum Geologists); (USA), 74 (CONF-900605--).

Hansen, R. O., \& Simmonds, M. (1993). Multiple-source Werner deconvolution. Geophysics, 58(12), 1792-1800. http://dx.doi.org/10.1190/1.1443394

Hartman, R. R., Teskey, D. J., \& Friedberg, J. L. (1971). A system for rapid digital aeromagnetic interpretation. Geophysics, 36(5), 891-918. http://dx.doi.org/10.1190/1.1440223

Idornighie, A. I., \& Olorunfemi, M. O. (1992). A Geoelectric Mapping of the Basement Structures of the Southcentral part of the Bida Basin and its Hydro Geological Implications. Journal of Mining and Geology, 28(1), 93-103.

Jain, S. (1976). An automatic method of direct interpretation of magnetic profiles. Geophysics, 41(3), 531-541. http://dx.doi.org/10.1190/1.1440631

Kilty, K. T. (1983). Werner deconvolution of profile potential field data. Geophysics, 48(2), 234-237. http://dx.doi.org/10.1190/1.1441463

Megwara, J. U., \& Udensi, E. E. (2013). Lineaments study using aeromagnetic data over parts of southern Bida basin, Nigeria and the surrounding basement rocks. International Journal of Basic and Applied Sciences, 2(1), 115-124.

Miller, H. G., \& Singh, V. (1994). Potential field tilt-a new concept for location of potential field sources. Journal of Applied Geophysics, 32(2), 213-217. http://dx.doi.org/10.1016/0926-9851(94)90022-1

Obaje, N. G. (2009). Geology and mineral resources of Nigeria (Vol. 120). Berlon (Germany): Springer. http://dx.doi.org/10.1007/978-3-540-92685-6

Obaje, N. G., Musa, M. K., Odoma, A. N., \& Hamza, H. (2011). The Bida Basin in north-central Nigeria: 
sedimentology and petroleum geology. Journal of Petroleum and Gas Exploration Research, 1(1), 001-013.

Ojo, S. B. (1990). Origin of a major magnetic anomaly in the Middle Niger Basin, Nigeria. Tectonophysics, 85, 153-162. http://dx.doi.org/10.1016/0040-1951(90)90410-A

O'leary, D. W., Friedman, J. D., \& Pohn, H. A. (1976). Lineament, linear, lineation: Some proposed new standards for old terms. Geological Society of America Bulletin, 87(10), 1463-1469. http://dx.doi.org/10.1130/0016-7606(1976)87<1463:LLLSPN>2.0.CO;2

Onyedim, G. C., Awoyemi, M. O., Ariyibi, E. A., \& Arubayi, J. B. (2007). Aeromagnetic imaging of the basement morphology in part of the Middle Benue Trough, Nigeria. Journal of Mining and Geology, 42(2), 157-163. http://dx.doi.org/10.4314/jmg.v42i2.18856

Onyewuchi, R. A., Opara, A. I., Ahiarakwem, C. A., \& Oko, F. U. (2012). Geological Interpretations Inferred From Airborne Magnetic and Landsat Data: Case Study of Nkalagu Area, Southeastern Nigeria. International Journal of Science and Technology, 2(4).

Reid, A. B., Allsop, J. M., Granser, H., Millett, A. J., \& Somerton, I. W. (1990). Magnetic interpretation in three dimensions using Euler deconvolution. Geophysics, 55(1), 80-91. http://dx.doi.org/10.1190/1.1442774

Salem, A., Williams, S., Fairhead, D., Smith, R., \& Ravat, D. (2008). Interpretation of magnetic data using tilt-angle derivatives. Geophysics, 73(1), L1-L10. http://dx.doi.org/10.1190/1.2799992

Salem, A., Williams, S., Fairhead, J. D., Ravat, D., \& Smith, R. (2007). Tilt-depth method: A simple depth estimation method using first-order magnetic derivatives. The Leading Edge, 26(12), 1502-1505. http://dx.doi.org/10.1190/1.2821934

Shekwolo, P. D. (1992). Regional hydrogeology of Bida Basin (Ph.D. Thesis). Ahmadu Bello University, Zaria, Nigeria.

Thompson, D. T. (1982). EULDPH: A new technique for making computer-assisted depth estimates from magnetic data. Geophysics, 47(1), 31-37. http://dx.doi.org/10.1190/1.1441278

Udensi, E. E. (2000). Interpretation of the total magnetic field over the Nupe Basin in west central Nigeria using aeromagnetic data. (Ph.D. Thesis). Ahmadu Bello University, Zaria, Nigeria.

Udensi, E. E., Osazuwa, I. B., \& Daniyan, M. A. (2003a). Trend analysis of the total magnetic field over the Bida Basin, Nigeria. Nigerian Journal of Physics, 15, 143.

Udensi, E. E., Osazuwa, I. B. \& Daniyan, M. A. (2003b). The origin and tectonic evolution of the Nupe Basin. Nigeria from aeromagnetic study. Zuma Journal of Pure and Applied Sciences, 5, 170-178.

Verduzco, B., Fairhead, J. D., Green, C. M., \& MacKenzie, C. (2004). New insights into magnetic derivatives for structural mapping. The Leading Edge, 23(2), 116-119. http://dx.doi.org/10.1190/1.1651454

Werner, S. (1953). Interpretation of Magnetic Anomalies at Sheet-Like Bodies, Sverges Geologiska Undersok, Ser.

\section{Copyrights}

Copyright for this article is retained by the author(s), with first publication rights granted to the journal.

This is an open-access article distributed under the terms and conditions of the Creative Commons Attribution license (http://creativecommons.org/licenses/by/3.0/). 